\title{
Male breast cancer: a review
}

\section{IS Fentiman}

Surgical Oncology, GKT School of Medicine, Guy's Hospital, London SE1 9RT, UK

\begin{abstract}
Male breast cancer (MBC) is rare, with the peak age of onset at 71 years. BRCA2 mutations are more frequent than BRCA1 with $20 \%$ of cases giving a family history. Risk factors for MBC are poorly understood and include working in high-ambient temperatures and exhaust fume exposure. MBC is associated with hyperoestrogenic states found in liver disease, Klinefelter's syndrome, gonadal dysfunction or obesity. Most information on treatment of MBC is derived from large randomized trials carried out in female patients. The small numbers of MBC seen in any unit annually has precluded significant trials being carried out.

Diagnosis and treatment of MBC is similar to that of female patients, but men tend to be treated with mastectomy rather than breastconserving surgery. The mainstay of adjuvant therapy or palliative treatment for advanced disease is endocrine, mostly tamoxifen. Prognosis of male patients is equal to that of stage-matched women, but men tend to fare worse because of delay in presentation, leading to a large proportion of patients presenting with stage III or IV disease. Increased input is needed for psychological support for male breast cancer patients. Specific therapeutic questions about MBC need international trials to obtain meaningful answers.
\end{abstract}

Published: 20/03/2009

Received: 16/02/2009

ecancer 2009, 3:140 DOI: 10.3332/ecancer.2009.140

Copyright: (c) the authors; licensee ecancermedicalscience. This is an Open Access article distributed under the terms of the Creative Commons Attribution License (http://creativecommons.org/licenses/by/2.0), which permits unrestricted use, distribution, and reproduction in any medium, provided the original work is properly cited.

Competing Interests: The authors have declared that no competing interests exist.

Correspondence to IS Fentiman. Email: ian.Fentiman@cancer.org.uk 


\section{Background}

Male breast cancer is a relatively rare disease in the western world accounting for $<1 \%$ of all breast cancers. The causes are poorly understood and most studies are small and underpowered so that treatment decisions derive from large trials in post-menopausal women. Although the outlook for men is the same as stage-matched women, overall the prognosis is worse because of delayed presentation-on average 6-10 months from symptom onset to diagnosis [1], with only slight improvement in survival over the last 25 years [2].

The incidence of MBC in Northwest Europe and North America is approximately $1 / 100,000$ but is increasing [3]. Disease frequency is higher among Jewish men at 2.3/100,000 and in countries with a high incidence of parasitic liver disease such as Egypt and Zambia [4,5]. In Japan, where the incidence of female breast cancer is low, the rate of $M B C$ is $<0.5 / 100,000$ [6].

\section{Risk factors}

Although several risk factors for MBC have been identified, most men with the disease have none other than increasing age (average age of diagnosis is 71 years, approximately ten years older than in women [7]. Most risk factors relate to either testicular malfunction or an increase in oestrogen (Table 1).

\section{Genetic}

As in women, risk of breast cancer increases with number of first degree relatives with the disease particularly with early age at diagnosis. In $15-20 \%$ of MBC cases there is a positive family history [8]. More rarely, men are found to have BRCA1 and BRCA2 mutations, usually the latter. A male BRCA2 carrier has a $6 \%$ lifetime risk of developing the disease, compared with $0.1 \%$ in the normal population [9]. MBC has been reported in those with Cowden syndrome [10], but not in men with $\mathrm{Li}$ Fraumeni syndrome. Individuals with Klinefelter's syndrome (XXY) have a 20 to 50 -fold increased risk of breast cancer and a mortality rate similar to that of females $[11,12]$.

\section{Occupation}

Men working in hot environments such as blast furnaces, steel works and rolling mills have increased risk of $\mathrm{MBC}$ [8]. Associations have also been found with occupations involving working with soap, perfume, petrol or exhaust fumes [13,14]. The responsible carcinogens are probably polycyclic aromatic hydrocarbons (PAH), present in tobacco smoke and exhaust emissions. Exposure to electromagnetic fields has been postulated as a risk factor but evidence for this is limited and negative [15].

\section{Radiation exposure}

Radiation exposure increases risk of breast cancer for both women and men [16]; small numbers of chest X-rays do not, but prolonged exposure to radiographs or radiotherapy may be harmful [17]. Radiotherapy has been used in high doses to treat gynaecomastia and a sevenfold increase in the relative risk of breast cancer has been reported in these patients [18]. Some institutions still use low-dose radiotherapy for this condition and the long-term effects of this remain to be seen [19]. Among the 45,880 survivors of an atomic bomb, MBC risk increased up to eightfold, depending on the extent of exposure [20].

\section{Endocrine factors}

$\mathrm{MBC}$ risk is affected by oestrogen/testosterone balance with increased rates in men taking exogenous oestrogens, such as prostate cancer patients and transsexuals [21,22]. Testicular dysfunction as a result of congenital inguinal hernia, infertility, testicular injury, orchidectomy and mumps orchitis at age increases risk of MBC by up to twelve-fold [23].

Obesity commonly causes hyperestrogenism in men and some studies suggest that it can double the risk of MBC [24,25]. Liver disease such as cirrhosis also causes hyperestrogenism associated with an increased risk of MBC [26]. A European multi-centre study with 74 cases and 1432 population controls reported a significant relationship between alcohol consumption and risk of $\mathrm{MBC}$ [27]: the odds ratio for alcohol intake $>90 \mathrm{~g} / \mathrm{d}$ was $5.89(\mathrm{Cl} 2.21-15.69)$. The risk of $\mathrm{MBC}$ rose by $16 \%$ for every $10 \mathrm{~g}$ of daily alcohol intake. Male breast cancer has been described in patients with hyperprolactinaemia due to pituitary adenomas [28]. There is however no proven link between gynaecomastia and male breast cancer [29].

\section{Presentation}

As in female patients, most males (75\%) complain of a painless mass [30]. Other presenting features include nipple retraction, nipple discharge, ulceration and pain [31]. Differential diagnosis 
Table 1: Risk factors for male breast cancer

\begin{tabular}{llc}
\hline & Feature & Relative risk \\
\hline Genetic & Family history & 2.5 \\
& BRCA 2 & $50-60$ \\
Klinefelter's syndrome & $20-50$ \\
Occupation & High temperature & 2.5 \\
Lifestyle & Exhaust emissions & 2 \\
& Alcohol & 4 \\
Obesity & 2 \\
Radiation exposure & Gynaecomastia & 1 \\
Endocrine factors & Higher economic status & 1.8 \\
& Chest wall radiotherapy & 7 \\
& Electromagnetic fields & 1 \\
& Oestrogen intake & 2 \\
& Bilateral orchidectomy & 2 \\
Undescended testis & 12 \\
Mumps aged >20 & 12 \\
Liver damage & 4 \\
& & \\
& & 2 \\
\hline
\end{tabular}

Table 2: TNM stage at presentation for male breast cancer

\begin{tabular}{cc}
\hline Stage & Proportion (\%) \\
I & 37 \\
II & 21 \\
III & 33 \\
IV & 9 \\
\hline
\end{tabular}

includes gynaecomastia, abscess, metastatic disease or rarely, sarcoma. Because the male breast is rudimentary and most tumours are central, nipple involvement is seen in up to $50 \%$ of cases at presentation [32]. Despite some increased awareness of $\mathrm{MBC}$, there is still a delay of 6-10 months from onset of symptoms to diagnosis [2]. Of the patients, $>40 \%$ of men present with stage III or IV disease (Table 2) $[29,30,33,34]$.

\section{Diagnosis}

As with symptomatic female patients, the diagnosis is made by triple assessment, with both mammography and ultrasound scanning having high sensitivity and specificity for male patients [35]. Fine needle aspiration cytology and core biopsies may be used, but core biopsy is preferred because it enables a definitives diagnosis to be made in the majority of cases. MR imaging has little role for determining extent of disease in male patients since the majority will be treated by mastectomy.

\section{Histopathology}

Most male breast cancers are invasive at presentation with only $10 \%$ having ductal carcinoma in situ (DCIS) (Table 3) $[29,32,33,36-38]$. The majority are invasive ductal carcinomas 
Table 3: Histopathological types of male breast cancer

\begin{tabular}{|c|c|}
\hline Histology & Percentage (\%) \\
\hline Invasive ductal & 90 \\
\hline Grade I & 20 \\
\hline Grade II & 55 \\
\hline Grade III & 25 \\
\hline Ductal carcinoma in situ & 10 \\
\hline Invasive papillary & 2 \\
\hline Medullary & 2 \\
\hline Mucinous & 1 \\
\hline Paget's & 1 \\
\hline Lobular & 1 \\
\hline
\end{tabular}

$(80 \%)$ with only $1 \%$ of male breast cancers being lobular in origin, since in the male breast, lobule development is dependant upon oestrogenic stimulation.

Paget's disease and inflammatory breast cancer occur in similar proportions in men and women with breast cancer. Rarer histological subtypes, medullary, tubular, mucinous and squamous have all been reported. Non-invasive disease is usually DCIS of low or intermediate grade, but lobular carcinoma in situ (LCIS) has been described, usually coexisting with invasive lobular carcinoma [39].

Oestrogen receptors are expressed in $90 \%$ of MBCs, a higher proportion than in women and up to $96 \%$ are progesterone receptor positive [40,41]. Human epidermal growth factor receptor 2 (Her-2) overexpression has been reported in $16 \%$, on average $[40,42,43]$ slightly lower than in females but its effects on prognosis are unclear [44].

\section{Management}

The principles of treatment of MBC are similar to those used for females with breast cancer. Men are less likely to have breastconserving surgery, radiotherapy or receive chemotherapy compared with stage-matched female cases [45]. Most breast units see few MBC patients each decade. Psychological support is very much orientated towards women, but psychological morbidity is also frequent amongst male patients who often have concerns about body image [46]. Additionally, MBC can be a very isolating diagnosis with some patients questioning their masculinity, and these concerns need to be addressed by those who are caring for the patient.

\section{Treatment of local disease}

\section{Surgery}

Surgery is the mainstay of treatment for MBC and mastectomy is the most commonly performed operation because of the size of the male breast and most cancers being central with early nipple involvement. Radical mastectomy was the treatment of choice but this is now infrequently necessary [23]. Tumours close or attached to the pectoralis major can be excised with a small amount of muscle.

Locally advanced tumours can be down staged with neoadjuvant therapy to enable mastectomy. For nonresponders, primary skin closure may not be possible after mastectomy so a latissimus dorsi or rectus sentinel node biopsy (SNB) is the standard of care in men and has the same sensitivity and specificity as that described in female patients [47]. When axillary nodes contain tumour, detected pre-operatively or after SNB a clearance should be performed.

\section{Endocrine therapy}

Since the majority of male breast cancers are oestrogen receptor positive $(E R+v e)$, endocrine therapy is an integral part of treatment. Studies of tamoxifen in men, given for two years, have shown improvement in both disease free, and so the effect of this treatment in men may have been underestimated. 
Aromatase inhibitors have been used to treat advanced MBC but their adjuvant role has yet to be determined [29].

\section{Radiotherapy}

The few small studies using radiotherapy in men show an improved local control but did not control for other prognostic variables $[48,49]$. MBC patients should be offered postoperative radiotherapy according to the guidelines drawn up for females. Those few men who have breast-conserving surgery should be offered post-operative radiotherapy. Men with large tumours, locally advanced disease, extensive axillary nodal involvement or poor prognostic factors such as high histological grade and vascular invasion should all be offered post-mastectomy radiotherapy.

\section{Chemotherapy}

Studies of adjuvant chemotherapy in MBC do show a benefit but again these were underpowered [50,51]. Adjuvant chemotherapy for MBC should be advised along the same principles as female patients although age and co-morbidity will render many unsuitable.

\section{Treatment of advanced disease}

Endocrine therapy is the usual treatment for metastatic MBC [52]. Orchidectomy has been used but selective oestrogen receptor modulator (SERM) therapy in the form of tamoxifen is now the treatment of choice. Aromatase inhibitors are not usually used as they only block peripheral oestrogen production that accounts for $80 \%$ of oestrogen production in men. There is a risk of aromatase inhibitors up-regulating testicular oestrogen production in those with an intact hypothalamic feedback loop.

Those few men with ER-ve tumours can be treated with chemotherapy. Additionally, the use of androgens, antiandrogens, steroids, oestrogens, progestins and aminoglutethimide for advanced disease in men has also been described.

\section{Prognosis}

Male and female patients with breast cancer are staged similarly, according to AJCC or UICC guidelines. Prognosis depends upon tumour size, histological grade, nodal status and hormone receptor status [53]. The most important prognostic factor is the lymph node status. Those who are node negative can expect a five-year survival rate of $90 \%$, compared with $65 \%$ five-year survival rate for node positive cases.

The number of involved nodes is also of prognostic significance: those with 1-3 positive nodes have a ten-year survival rate of $44 \%$, compared with $14 \%$ for patients with $\geq$ four nodes involved [54]. Histological tumour grade also plays a role: grade I patients have a five-year survival rate of $76 \%$, dropping to $66 \%$ for those with grade II tumours and $43 \%$ for grade III cases. Patients with ER/PR+ve tumours fare better than those with ER/PR-ve disease.

Overall, the prognosis is equivalent to that in stage-matched female patients. MBC patients tend to fare worse because of late presentation associated with more advanced disease. Because MBC cases tend to be older than female patients, there is an increased incidence of co-morbidities, which could adversely affect their prognosis [29].

\section{Psycho-social aspects}

In females with breast cancer, clinically significant anxiety/depression occurs in up to $25 \%$ of cases $[55,56,57]$. Until recently, no structured psychosocial studies have been reported in MBC. In depth interviews of MBC patients indicated seven major areas of concern: delay in diagnosis, shock, stigma, body image, causal factors and lack of informational and emotional support [58]. Focus group discussions have suggested a particular need for gender-specific information on MBC together with provision of support [59].

In a national study, Brain et al administered questionnaires to 161 MBC patients [60]. There was a low incidence of clinical levels of anxiety and depression, $6 \%$ and $1 \%$, respectively, but $23 \%$ stated that they had cancer-associated distress. These low levels of psychological morbidity may have related to the selfselected nature of the participants. In a much smaller study, Donovan et al [61] reported four themes of experience for MBC patients, making sense of the diagnosis, challenge to masculinity, stigma of the diagnosis and the problems of interacting with health-care services. There is an evident need for national protocols for both information and support for men diagnosed with breast cancer.

\section{Acknowledgement}

Article was originally posted in the Breast Cancer Forum (http://www.breastcancer.org.uk). This forum is sponsored by an unrestricted grant from Sanofi-Aventis. 


\section{References}

1. Joshi MG, Lee AK, Loda M et al (1996) Male breast carcinoma:an evaluation of prognostic factors contributing to a poorer outcome Cancer 77 490-8 PMID: 8630956 doi: 10.1002/(SICl)1097-0142(19960201) 77:33.0.CO;2

2. O' Malley CD, Prehn AW, Shema SJ et al (2002) Racial/ethnic differences in survival rates in a population based series of men with breast cancer Cancer 94 2836-42 PMID: 12115370 doi: 10.1002/cncr. $\underline{10521}$

3. Hodgson NC, Button JH, Franceschi D et al (2004) Male breast cancer:is the incidence increasing? Ann Surg Oncol 118 751-5 PMID: 15289238 doi: 10.1245/ASO. 2004.01.001

4. El-Gazayerli MM and Abdel-Aziz AS (1963) On bilharziasis and male breast cancer in Egypt: a preliminary report and review of the literature $\mathrm{Br} \mathrm{J}$ Cancer 17 566-71 PMID: 14111594

5. Bhagwandin S (1972) Carcinoma of the male breast in Zambia East Afr Med J 49 176-9

6. Waterhouse J, Muir C, Correa P et al (1976) Cancer incidence in five continents vol 3 (Lyon: IARC Sci Publ) $p$ 15.

7. Anderson WF, Althuis MD, Brinton LA et al (2004) Is male breast cancer similar or different from female breast cancer? Br Cancer Res Treat 83 77-86 PMID 14997057 doi:10.1023/B:BREA.0000010701.08825.2d

8. Basham VM, Lipscombe JM, Ward JM et al (2002) BRCA1 and BRCA2 mutations in a population-based study of male breast cancer Breast Cancer Res 41 R2 PMID: 11879560 doi: $10.1186 / \mathrm{bcr} 419$

9. Friedman LS, Gayther SA, Kurosaki T et al (1997) Mutation analysis of BRCA1 and BRCA2 mutations in a male breast cancer population Am J Hum Genet 60 3139 PMID: 9012404

10. Fackenthal JD, Marsh DJ, Richardson AL et al (2001) Male breast cancer in Cowden syndrome patients with germline PTEN mutations J Med Genet 38 159-64 PMID: 11238682 doi: $10.1136 /$ jmg.38.3.159

11. Harnden DG, Maclean N and Langlands AO (1971) Carcinoma of the breast and Klinefelter's syndrome $\mathrm{J}$ Med Genet 8460 PMID: 4337761 doi: 110.1136/jmg.8.4. $\underline{460}$

12. Price $\mathrm{WH}$, Clayton JF, Wilson J, Collyer S and De Mey $\mathrm{R}$ (1985) Causes of death in X chromatin positive males (Klinefelter's syndrome) $\mathrm{J}$ Epidemiol Community Health 39 330-6 PMID: 4086964 doi: 10.1136/jech.39.4.330
13. McLaughlin JK, Malker BR, Blot WJ et al (1988) Occupational risks for male breast cancer in Sweden $\mathrm{Br}$ $\mathrm{J}$ Indust Med 4 275-6 PMID 3378005

14. Hansen J (2000) Elevated risk for male breast cancer after exposure to gasoline and vehicular combustion products $A m \mathrm{~J}$ Ind Med 37 349-52 PMID: 10706746 doi: 10.1002/(SICl)1097-0274(200004)37:43.0.CO;2-L

15. Loomis DP (1992) Cancer of breast among men in electrical occupations Lancet 339 1482-3 PMID: 1351155 doi: 10.1016/0140-6736(92)92078-T

16. Lenfant-Pejovic $\mathrm{M}-\mathrm{H}$, Mlika-Cabanne $\mathrm{N}$, Bouchardy $\mathrm{C}$ et al (1990) Risk factors for male breast cancer: a FrancoSwiss case-control study Int J Cancer 45 661-5 PMID: 2323842 doi: $10.1002 / i j c .2910450415$

17. Olsson $H$ and Ranstam $J(1988)$ Head trauma and exposure to Prolactin-elevating drugs as risk factors for male breast cancer J Natl Cancer Inst 80 679-83 PMID: 3373557 doi: 10.1093/jnci/80.9.679

18. Sasco AJ, Lowenfels $A B$ and Pasker de Jong $P$ (1993) Epidemiology of male breast cancer: a meta-analysis of published case-control studies and discussion of selected aetiological factors Int J Cancer 53 539-49 PMID 8436428 doi: 10.1002/ijc.2910530403

19. Dicker AP (2003) The safety and tolerability of low-dose irradiation for the management of gynaecomastia caused by antiandrogen monotherapy Lancet Oncol 4 30-6 PMID: 12517537 doi: 10.1016/S1470-2045(03) 00958-6

20. Ron E, Ikeda T, Preston DL et al (2005) Male breast cancer incidence among atomic bomb survivors $\mathrm{J}$ Natl Cancer Inst 97 603-5 PMID: 15840883 doi:10.1093/inci/ dji097

21. McClure JA and Higgins CC (1951) Bilateral carcinoma of male breast after estrogen therapy JAMA 146 7-9

22. Symmers WSC (1968) Carcinoma of the breast in transsexual individuals after surgical and hormonal interference with the primary and secondary sexual characteristics $\mathrm{Br}$ Med J 2 83-5 PMID: 5689553 doi: $\underline{10.1136 / \mathrm{bmj} .2 .5597 .83}$

23. Thomas DB, Jimenez LM, McTiernan A et al (1992) Breast cancer in men: risk factors with hormonal implications Am J Epidemiol 135 734-48 PMID: 1350708

24. Thomas DB, Jimenez LM, McTiernan A et al (1992) Breast cancer in men: risk factors with hormonal implications Am J Epidemiol 135 734-48 PMID: 1350708

25. Johnson KC, Pan S Mao Y (2002) Risk factors for male breast cancer in Canada, 1994-1998 Eur J Cancer Prev 11 253-63 PMID: 12131659 doi: 10.1097/00008469200206000-00009 
26. Hsing AW, McLaughlin JK, Cocco P et al (1998) Risk factors for male breast cancer (United States) Cancer Causes Control 9 269-76 PMID: 9684707 doi: 10.1023/ A:1008869003012

27. Guenel P, Cyr D, Sabroe S et al (2004) Alcohol drinking may increase the risk of breast cancer in men:a European population-based case-control study Cancer Causes Control 15 571-80 PMID: 15280636 doi: 10.1023/ B:CACO.0000036154.18162.43

28. Volm MD, Talamonti MS, Thangavelu M et al (1997) Pituitary adenoma and bilateral male breast cancer:an unusual association $\mathrm{J}$ Surg Oncol 64 74-8 PMID: 9040805 doi: 10.1002/(SICl)1096-9098(199701)64:13.0. CO;2-W

29. Fentiman IS, Fourquet $A$ and Hortobagyi GN (2006) Male breast cancer Lancet 367 595-604 PMID: 16488803 doi: 10.1016/S0140-6736(06)68226-3

30. Ribeiro GG, Swindell R, Harris M et al (1996) A review of the management of the male breast carcinoma based on an analysis of $\mathbf{4 2 0}$ treated cases Breast 5 141-6 doi: 10.1016/S0960-9776(96)90058-2

31. van Geel AN, van Slooten EA, Mavrunac M et al (1985) A retrospective study of male breast cancer in Holland $\mathrm{Br}$ J Surg 72 724-7 PMID: 2994794 doi: 10.1002/bjs. $\underline{1800720918}$

32. Goss PE, Reid C, Pintilie M et al (1999) Male breast carcinoma:a review of 229 cases who presented to the Princess Margaret Hospital during 40 years: 1955-1996 Cancer 85 629-39 PMID: 10091736 doi: 10.1002/(SICI) 1097-0142(19990201)85:33.0.CO;2-V

33. Scheike O (1975) Male breast cancer Acta Pathol Microbiol Scand S251 3-35 PMID 1138536

34. Ramantanis G, Besbeas S, Garas JG et al (1980) Breast cancer in the male: a report of 138 cases World J Surg 4 621-4 PMID: 7233931 doi: 10.1007/BF02401650

35. Stewart RAL, Howlett DC and Hearn FJ (1997) Pictorial review: the imaging features of male breast disease Clin Radiol 52 739-44 PMID: 9366531 doi: 10.1016/S00099260(97)80151-1

36. Donegan WL, Redlich PN, Lang PJ and Gall MT (1998) Carcinoma of the breast in males Cancer 83 498-509 PMID: 9690543 doi: 10.1002/(SICl)1097-0142(19980801) 83:33.0.CO;2-R

37. Stalsberg H, Thomas DB, Rosenblatt KA et al (1993) Histologic types and hormone receptors in breast cancer in men: a population-based study in 282 United States men Cancer Causes Control 4 143-51 PMID: $\underline{8386948}$ doi: $10.1007 / B F 00053155$
38. Giordano SH, Cohen DS, Buzdar AU et al (2004) Breast carcinoma in men: a population based study Cancer 101 51-7 PMID: 15221988 doi: 10.1002/cncr.20312

39. Michaels BM, Nunn CR and Roses DF (1994) Lobular carcinoma of the male breast Surgery 115 402-5 PMID: 8128366

40. Rayson D, Erlichman C, Suman VJ et al (1998) Molecular markers in male breast carcinoma Cancer 83 2139-49 PMID: 9827718 doi: 10.1002/(SICI)1097-0142(19981115) 83:103.0.CO;2-F

41. Meijer-van Gelder ME, Look MP, Bolt-de Vries $\mathrm{J}$ et al (2001) Clinical relevance of biologic factors in male breast cancer Breast Cancer Res Treat 68 249-60 PMID: 11727961 doi: 10.1023/A:1012221921416

42. Wang-Rodriguez J, Cross K, Gallagher S et al (2002) Male breast cancer: correlation of ER, PR, Ki-67, HER2/neu and P53 with treatment and survival, a study of 65 cases Mod Pathol 15 853-61 PMID: 12181271 doi: 10.1097/01.MP.0000022251.61944.1D

43. Dakin Haché K, Gray S, Barnes PJ et al (2007) Clinical and pathological correlations in male breast cancer: intratumoral aromatase expression via tissue microarrays Breast Cancer Res Treat 105 169-75 PMID: 17268818 doi: $10.1007 / \mathrm{s} 10549-006-9448-9$

44. Bloom KJ, Govil H, Gattuso P et al (2001) Status of HER-2 in male and female breast carcinomas Am J Surg 82 389-92 PMID: 11720677 doi: 10.1016/S0002-9610(01) 00733-4

45. Scott-Connor CE, Jochimsen PR, Menck HR et al (1999) An analysis of male and female breast cancer treatment and survival among demographically identical pairs of patients Surgery 126 775-80 PMID: 10520928 doi:10.1016/S0039-6060(99)70135-2

46. France L, Michie S, Barrett-Lee P et al (2000) Male breast cancer: a qualitative study of male breast cancer Breast 9 342-8 PMID: 14965759 doi: 10.1054/brst.2000.0173

47. Albo D, Ames FC, Hunt KK et al (2003) Evaluation of lymph node status in male breast cancer patients:a role for sentinel lymph node biopsy Breast Cancer Res Treat 77 9-14 PMID: 12602900 doi: 10.1023/A: 1021173902253

48. Cutuli B, Lacroze M, Dilhuydy JM et al (1995) Male breast cancer:results of the treatments and prognostic factors in 397 cases Eur J Cancer 31A 1960-64 PMID: 8562148 doi: 10.1016/0959-8049(95)00366-5

49. Erlichman C, Murphy KC and Elhakim T (1984) Male breast cancer: a 13 year review of 89 patients $\mathrm{J}$ Clin Oncol 2 903-9 PMID: 6086848 
50. Giordano SH, Perkins GH, Broglio K et al (2005) Adjuvant systemic therapy for male breast cancer Cancer 104 2359-64 PMID: 16270318 doi: 10.1002/cncr.21526

51. Yildirim E and Berberoglu U (1998) Male breast cancer: a 22 year experience Eur J Surg Oncol 24 548-52 PMID: 9870732 doi: $10.1016 / S 0748-7983(98) 93608-3$

52. Jaiyesimi IA, Buzdar AU, Sahin AA et al (1992) Carcinoma of the male breast Ann Internal Med 117 771-7 PMID: 1416579

53. Irvine $\mathrm{T}$ and Fentiman S (2007) Male breast cancer $C M L$ Breast Cancer 19 1 1-6

54. Guinee VF, Olsson H, Moller T, Shallenberger RC, van den Blink JW et al (1993) The prognosis of breast cancer in males. A report of 335 cases Cancer 711 154-61 PMID: 8416712 doi: 10.1002/1097-0142(19930101)71:13.0.CO;2

55. Morris T, Goodyer HS and White P (1977) Psychological and social adjustment to mastectomy: a two year follow-up study Cancer 40 2381-7 PMID: 922679 doi: 10.1002/1097-0142(197711)40:53.0.CO;2-B
56. Maguire GP, Lee EG, Bevington DJ et al (1978) Psychiatric problems in the first year after mastectomy Br Med J 1 963-5 PMID: 565239 doi: 10.1136/bmj.1.6118. $\underline{963}$

57. Dean C (1987) Psychiatric morbidity following mastectomy: preoperative predictors and types of illness J Psychosom Res 31 385-92 PMID: 3625592 doi: 10.1016/0022-3999(87)90059-6

58. France L, Michie S, Barrett-Lee P et al (2000) Male breast cancer: a qualitative study of male breast cancer Breast 9 342-8 PMID: 14965759 doi: 10.1054/brst.2000.0173

59. Williams BG, Iredale R, Brain K et al (2003) Experiences of men with breast cancer: an exploratory focus group study $\mathrm{Br} J$ Cancer 89 1834-6 PMID: 14612888 doi: 10.1038/sj.bjc. 6601305

60. Brain K, Williams B, Iredale R et al (2006) Psychological distress in men with breast cancer J Clin Oncol 24 95101 PMID: 16382118 doi: $10.1200 / J C O .2006 .10 .064$

61. Donovan et al http://www.medscape.com/viewarticle/ 566993 (accessed 15 November 2008) 